\title{
ECONOMIC SECTOR PERFORMANCE AND GROWTH: CONTEMPORARY APPROACHES IN THE CONTEXT OF SUSTAINABLE DEVELOPMENT
}

\author{
Toma LANKAUSKIENĖ \\ Vilnius Gediminas Technical University, \\ Faculty of Enterprise Economics and Management \\ Saulètekio al. 11, LT-10223, Vilnius, Lithuania \\ E-mail: toma.lankauskiene@gmail.com \\ Manuela TVARONAVIČIENĖ \\ Vilnius Gediminas Technical University, \\ Faculty of Enterprise Economics and Management \\ Saulètekio al. 11, LT-10223, Vilnius, Lithuania \\ E-mail:manuela@vgtu.lt
}

doi:10.13165/IE-13-7-3-07

\begin{abstract}
Lack of sufficient attention to the role of economic sectors in terms of economic growth in Lithuania prompted very reasonable necessity to analyse foreign literature on the topic. In order to provide an in-depth coverage of possible contemporary perceptions of economic sectors and economic growth relations, many pieces of the relevant foreign scientific literature were overviewed in the context of sustainability. The following main insights were distinguished: the structure of a country's economy is the key factor that distinguishes successful countries from the unsuccessful ones and is of vital importance for economic growth; foreign scientists most commonly define the performance of economic sectors targeted at economic growth as structural changes; the performance of economic sectors targeted at a country's economic growth through the perspective of production input cannot be implied without productivity phenomenon in the context of sustainable development.
\end{abstract}

JEL classification: $\mathrm{O} 1$.

Keywords: economic sectors, economic structure, economic growth, sustainable development.

Reikšminiai žodžiai: ekonomikos sektoriai, ekonomikos struktūra, ekonominis augimas, darni plètra.

\section{Introduction}

Economic sectors (Jaimovich, 2011; Halkos, Tzeremes, 2008; Tanuwidjaja, Thangavelu, 2007; Sonobe et. al., 2004; Lankauskiene, Tvaronaviciene, 2012), production (Bond 
et al., 2010; Sarkar, 2007; Briec, Cavaignac, 2007; Kosempel, 2004; Tvaronaviciene, Lankauskiene, 2013) and other different factors determining the development of economic sectors (e.g. Karnitis, 2011; Grybaite, 2011; Stańczyk, 2011; Balkyte, Tvaronaviciene, 2011; Kaźmierczyk, 2012, Lankauskiene, Tvaronaviciene, 2012) are vitally popular topics in contemporary scientific literature. As researches related to economic structures, generally referred to as structural economics, are widespread in foreign scientific literature of development economics, this movement in Lithuania is especially young. Reasonably, in the egg of this phenomenon, in order to gain a deeper insight into the topicality of the problem of economic sectors and economic growth, the analysis of contemporary scientific articles will be overviewed, by emphasising the concepts of economic sector performance and economic growth. The purpose of the article is to overview the contemporary perceptions of economic sector performance and economic growth in the context of sustainability. The relevant scientific literature will be overviewed to reach the targeted purpose and the main useful insights will be provided.

\section{Interrelation between Sustainable Development, Economic Growth and Economic Sector}

\subsection{Sustainable Development and Economic Growth}

Economic growth and development is most generally perceived as an increase in the standard of living of a nation's population associated with sustained growth from a simple, low-income economy to a modern, high-income economy. Its scope includes the process and policies by which a nation improves the economic, political, and social wellbeing of its people. Economic progress is an essential phenomenon for the development elaboration of countries. Most generally, economic development encompasses extensive economic growth (output enlargement, using more resources) and intensive economic growth, namely productivity increase, innovation implementation or economic shakeup, creation of new jobs. Economic development is a process that can be defined as appointive mobilisation of human, financial, organisational, physical and natural resources in order to improve the quality of competitive services and products and to increase their quantity for the community. Moreover, many different factors can determine the development of a country (Lankauskiene, Tvaronaviciene, 2011). The main goal of economic growth and development is to foster the speed of asset creation. Furthermore, every nation tries to put all efforts to reach the maximum results and improve its developmental level, as the well-being of people depends on this (Lankauskiene, Tvaronaviciene, 2011). As development is not a purely economic phenomenon, it is perceived as a multidimensional process involving the reorganisation and reorientation of the entire economic and social systems. By adding the dimension of environment, the term of "sustainable development" is obtained, which is extremely popular in contemporary scientific literature (Tvaronaviciene, Lankauskiene, 2012). In the following publication, the dimensions of sustainability and security have been indicated (Lankauskiene, Tvaronaviciene, 2012). 
Sustainable development is a complex notion that is treated differently. On one hand, it is very broad as it may be related to competitiveness of a given country (Balkyte, Tvaronaviciene, 2010), and, on the other hand, to adopt a very practical approach, sustainable development is estimated by a broad array of indicators (Tvaronaviciene, Lankauskiene, 2011).The term "sustainable development" emerged in the context of development and growing awareness of an imminent ecological crisis. This conception became rather widespread around the end of the 20th century. It was realised that economic growth was of vital importance, but it had to be a different kind of growth, targeted at the combination of the needs of people and sensitive to the needs of the environment. Sufficiency and not economic efficiency should be the goal. A distinction needs to be drawn between growth - quantitative change - and development - qualitative change (Du Pisani, Jacobus, 2006). The concept of sustainable development is more profound and comprehensive than economic growth. The essence of sustainable development is clear enough - most generally it is perceived as economic development meeting human needs at present and not reducing its wealth opportunities in the future (Ciegis, Ramanauskiene, 2009). According to the World Bank definition of 1992, "sustainable development is a development that continues". Another scientific article states that "sustainable development is a development that meets the needs at present without compromising the ability of future generations to meet their own needs" (Du Pisani, Jacobus, 2006). Robert Allen (1980) defined sustainable development as "development that is likely to achieve lasting satisfaction of human needs and improvement of the quality of human life".

Although the concept of sustainable development has been created for a more sophisticated society that cares about the wealth-being of the next generations, this issue has some opponents. The term of "sustainable development" is criticised by others because of its vagueness. Philosopher Luc Ferry described this term as obligatory, but he found it also absurd or rather so vague, that it said nothing. He also added that the above-mentioned term was trivial by a proof by contradiction and presented the idea of sustainable development as untenable development, this term was more charming than meaningful (Ruchi, 2009).

Most people point to the positive impact of sustainable development, and in this article we will reasonably focus on its beneficial side. According to the thoughts of the French geographer Sylvie Brunel, the ideas of sustainable development can hide a will of protectionism from the developed country to impede the development of other countries. He represents the idea that sustainable development serves as a pretext for protection and is perfectly helping capitalism denial. Furthermore, the concept of sustainable development, according to Dietrich Bonhoeffer, is defined as "the ultimate test of a moral society is the kind of the world that it leaves to its children" (Ruchi, 2009; Tvaronaviciene, Lankauskiene, 2011).

\subsection{Sustainable Development and Economic Sectors}

Processes of modern economic growth and catch-up do not merely involve significant increase in productivity levels and also entail changes in the distribution of inputs and outputs across sectors. Kuznets has stated that "it is impossible to attain high 
rates of growth per capita or per worker without commensurate the substantial shifts in the shares of various sectors" (Kuznets, 1979). The hypothesis that structural change is an important source of growth and productivity improvement is a central tenet of the growth- accounting literature and is derived from classical models of a dual economy (Lewis, 1954). Every country's economy is composed of economic sectors, while composition and development of economic sectors is a rather new trend in economics and is called "structural economics".

Economic growth cannot be perceived without the role of economic sectors, as they are the constituents of our economy. Structural change is the central insight of development economics. Economic growth reflects in economic sector performance and entails structural change. Structural change, narrowly defined as the reallocation of labour across economic sectors, featured in the early literature on economic development by Kuznets (1966). As labour and other resources move from traditional to modern economic activities, overall productivity rises and income expands. The nature and speed with which structural transformation takes place is considered as one of the key factors that differentiates successful countries from unsuccessful ones. Therefore, the new structural economists argue that economic structures should be the starting point for comparative economic analysis and the design of appropriate policies. And for the process of sustainable development to elaborate (e.g. Lankauskiene, Tvaronaviciene, 2012), it is of vital importance for economic sectors to develop in a sustainable manner. Sustainable development is now associated with increase in the living standards through economic progress (Lankauskiene, Tvaronaviciene, 2011; Lankauskiene, Tvaronaviciene, 2012), encompassing the development of knowledge-based and innovation susceptible sectors, but not with exploiting non-renewable natural resources (Tvaronaviciene, Lankauskiene, 2013).

The process of structural change has been widely discussed in the relevant foreign scientific literature, starting with the factors that determine the performance of economic sectors and structural changes and ending with the actual insights and various conclusions about the relevant economic structure targeted at a country's development. On the contrary, in the relevant Lithuanian scientific literature, the issue of economic structure fostering economic growth is vaguely analysed. Only several scientists have focused on the analysis of GDP and the share of employment. Stankevicius (2006) overviews the structure of the Lithuanian economy and its change after the World War I. Balciunas (2000) and Misiunas, Kaminskiene (1999) researched the structure of the Lithuanian economy when the Baltic countries created market economy. In their article, Matuzeviciute, Skuncikiene, Tamosaityte (2010) analyse the structure of economy, but the changes are not evaluated purposively in the context of Lithuania's economic growth. Recently, Vitas (2012) defended a PhD thesis entitled "The analysis and evaluation of economic structural changes in the Baltic States". Vitas has proposed a model for the evaluation of structural changes, i. e. the effectiveness of structural changes. Two more publications were issued on the subject of economic sectors (Lankauskiene, Tvaronaviciene, 2012; Tvaronaviciene, Lankauskiene, 2013). As economic sector performance, structural changes can be the main contributors to a country's economic growth this competitive advantage has already been recognised and well developed by advanced nations, while in Lithuania this issue attracts vague attention. As a result, we imply that 
for this reason it is of vital importance for Lithuania to dedicate relevant attention to sustainable economic sector performance targeted at the country's sustainable economic growth. This strengthens the need for this article.

\section{Economic Sector Performance Opportunities}

As stated above, every economy consists of economic sectors. The term of economic structure reflects the part occupied by each sector. Most popularly, it is reflected by the share of labour force in each sector. In this section, we will concentrate on possible economic sector performance opportunities in the structure of economy presented in the relevant scientific literature.

Economic growth and generation of income ultimately depends on the competitive performance of individual enterprises. The competitiveness of these enterprises in turn depends on the relative abundance (and hence cost) of resources, as well as the incentives and capabilities to use them in a productive and sustainable manner. Even though many determinants, such as macroeconomic stability, the corporate tax rate or the operation of factor markets, are thus shaped by the general business environment, the relative intensity in factor use, the incentives to pursue opportunities, and the specific capabilities required for transforming them into successful business vary between sectors. As a consequence, countries differ greatly in their sectoral growth and performance. Within an identical macroeconomic setting, they show considerable strength in some industries and weaknesses in others. Based on the goals of the Lisbon Agenda, the comparison of aggregate measures can only provide an incomplete picture of European competitiveness. Competitiveness is a multifaceted target for which no single and fully comprehensive measure exists. The multitude of objectives must be taken into account when striving for a 'general' picture (Peneder, 2009). Authors assess the competitive performance of European sectors along the following set of ten selected indicators:

Growth

- The growth of value added indicates an economy's success in creating income and thus its ability to increase material well-being. For given constraints with respect to a society's non-economic goals, such as social fairness or ecological sustainability, it is probably the most straightforward target of economic activity.

- The growth of employment or hours worked indicates not only success in mobilizing productive resources, but also the ability to offer people jobs and participation. As labour input is also a cost factor in production, its growth is not unconditional. If it is meant to be sustained, the growth of value added and productivity must keep pace accordingly.

\section{Productivity}

- Labour productivity is the ratio of output (either gross output or value added) to labour input (either employment or hours worked). Integrating changes in inputs and outputs into a single measure, it reflects competitiveness more accu- 
rately than the aforementioned growth of output and employment. In this study, we define labour productivity as value added per hour worked.

- Multifactor productivity (MFP) additionally nets out the returns to all other inputs, i.e. capital (and intermediates in the case of a gross output specification), and is therefore the most comprehensive measure of the efficiency of operations. Multifactor productivity is calculated as a residual, i.e. the gain in output which cannot be assigned to any measurable input.

\section{Profitability}

- The net profit margin is the ratio of after-tax revenue net of extraordinary items (and associated taxes) to sales. Indicating the efficient translation of sales into profits, the net profit margin tells how much profit is made for every dollar of revenue generated.

- Indicating the efficient use of assets to generate profits, the return on assets (ROA) is calculated as the ratio of after-tax profit net of extraordinary items to assets. The ROA figure offers an idea of how effectively a company is converting its available investment funds into net income, both through debt and equity financing.

\section{International trade}

- The revealed comparative advantage (RCA) indicator measures trade specialisation. In this study, it is defined as the logarithm of the export to import relation of one sector divided by the export to import relation of all sectors. Positive RCA values indicate comparative advantages and negative values represent comparative disadvantages of a particular industry.

- Export market shares reflect the capacity to respond to external demand or open up new markets in direct comparison to international competitors. They show how much of the total 'world' export is covered by the export.

\section{Foreign direct investments (FDI)}

- The ratio of inward FDI stock to value added indicates the contribution of FDIs to capital formation, stimulating value added and employment but also the acquisition of new technology and management practices in the host market.

- Analogously, the ratio of outward FDI stocks to value added reflects a corresponding outflow of capital. However, it can also be an indication of corporate strength, where companies venture abroad to seize opportunities from foreign markets and resources (Peneder, 2009).

In addition, the following performance possibilities of economic sectors could be distinguished in scientific literature: structural change (e.g. Timmer and Vries, 2008, Timmer and Vries, 2007, Havlik, 2005), structural transformation (Vries et al., 2012, Vries et al.). It could be stated that while talking about the expression of economic sector performance in the structure of economy and economic growth, the following performance opportunities could be distinguished: structural change, structural transformation, structural growth, structural development. It is important to note that structural change and transformation are quite similar expressions, as well as structural growth and development. In this particular research, we will overview which one of those con- 
cepts is the most widespread in the relevant scientific literature, while considering the economic sector performance and economic growth phenomenon, but before that it is very important to distinguish the sectoral performance driving forces in order to gain a deeper insight into this topic.

\section{Determinants of Sector Performance}

Based on the reform agenda agreed upon in Lisbon, enterprise and industrial policies require a detailed understanding of the competitive process at the level of individual industries and sectors (Peneder, 2009).Within this context, the current study on sectoral growth drivers aims to identify the major determinants, patterns and trends in European competitiveness from a distinctly sectoral perspective. The first part of this study investigates European sectoral competitiveness, assessing the relative strengths and weaknesses of European industries with respect to the various dimensions of performance, such as the growth of value added, employment, labour and multifactor productivity, profitability, international trade, and foreign direct investments. The second part now turns to an investigation of the major determinants or 'drivers' of sectoral growth (Peneder, 2009).

Figure 1. Stylised model of selected sectoral performance drivers

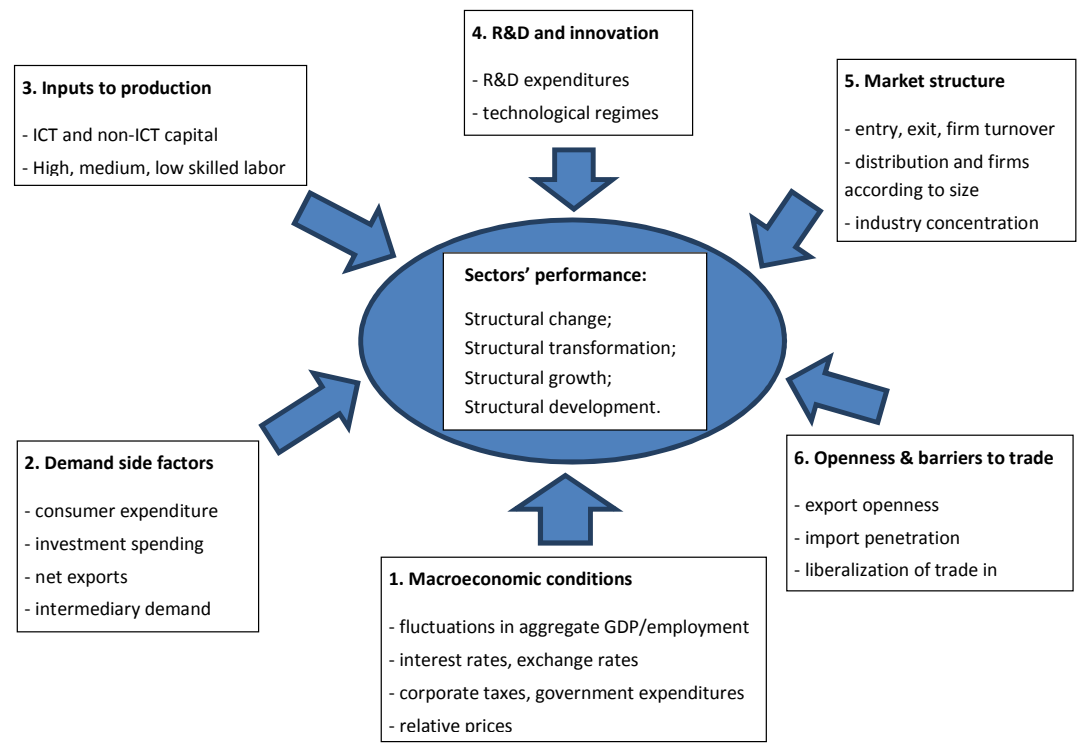

Source: compiled by authors referring to Peneder, M., 2009. Sectoral growth drivers and competitiveness in the European Union. European Commission, Enterprise and industry, European Communities, p. 1-542. 
Sectoral performance is driven by a myriad of distinct sources. At present, no single, comprehensive theory exists which can explain the role of these elements within a jointly integrated economic model. However, many of them are the subject matter of different strands of economic research. Accordingly, this study is organised according to six groups of related factors: macroeconomic conditions, demand side factors, inputs to production, $\mathrm{R} \& \mathrm{D}$ and innovation, market structure, and finally openness and barriers to trade (Peneder, 2009).

Figure 1 illustrates the six major dimensions of sectoral performance. First, macroeconomic conditions affect sectoral performance by defining the environment within which companies and industries operate.

\section{Contemporary Perceptions of Economic Sector Performance and Economic Growth}

In line with the purpose of this article, contemporary approaches followed in the relevant scientific literature with regard to economic sector performance targeted at a country's economic growth will be overviewed, by placing particular focus on inputs to production or production factors as sectoral performance drivers in the context of sustainability when making conclusions. Moreover, we will concentrate on the expression of economic sector performance, i.e. after the scientific literature overview it will become clear which one of the expressions is the most widespread, while talking about economic sector performance in economic structure. In order to have a more in-depth coverage, all articles in the Structural Change and Economic Dynamics Journal from the period of 2013-1996 will be overviewed, including some other scientific papers.

Peneder's paper "Industrial Structure and Aggregate Growth" aims for an empirical validation of the impact of industrial structure on aggregate income and growth. Various mechanisms for the linkage between meso-structure and macro-performance are identified: the income elasticity of demand, the structural bonus versus burden hypotheses, differential propensities towards entrepreneurial discovery, and producer or user related spillovers. After discussing detailed results from conventional shift-share analysis, dynamic panel estimations are applied to a standard growth model augmented by structural variables. Based on data for 28 OECD countries, the results confirm that industrial structure has been a significant determinant of macroeconomic development and growth in the 1990s (Peneder, 2003).

One more paper examines the role of structural change in explaining aggregate productivity growth in the manufacturing sector of four Asian countries over the period 1963-1993. The conventional shift-share analysis is used to measure the impact of shifts in both labour and capital inputs. The results do not support the structural-bonus hypothesis, which states that during industrial development, factor inputs shift to more productive branches (Timmer, Szirmai, 2000).

The following paper implies that the structural characteristics of an economy belong to the most important indicators of a country's or region's economic development. The shares of manufacturing, agriculture and services in total employment, as well as the 
shares of employment in different occupational and educational groups are closely correlated to aggregate indicators of wealth. It is also widely known that the economies of the former socialist Central and Eastern European countries (CEEC) have faced substantial problems of reallocating resources from unproductive to more productive uses on their way to a closer integration into the world economy. They started their transition to market economies with an employment structure that was heavily centred on industrial (and in some countries also agricultural) employment, extremely large enterprises and an almost complete predominance of state owned firms. It thus comes as no surprise that these countries and their regions have experienced substantial structural change since the start of market-oriented reforms (Huber, Mayerhofer, 2006).

Another paper entitled "Structural Change and the Growth of Industrial Sectors: Empirical Test of a GPT Model" investigates the empirical relevance of a model of structural change and the growth of industrial sectors. The model analyses the process of diffusion of general-purpose technologies (GPTs) and how this affects the dynamic performance of manufacturing and service industries. The empirical analysis studies the dynamics and the determinants of labour productivity growth for a large number of sectors in 18 OECD countries over the period 1970-2005. The results of dynamic panel data and cross-sectional analysis provide support for the empirical validity of the model. Industries that are close to the core of ICT-related GPTs are characterised by greater innovative capabilities and have recently experienced a more dynamic performance. Relatedly, countries that have been able to shift their industrial structure toward these high-opportunity manufacturing and service industries have grown more rapidly (Castellacci, 2010).

Another paper implies that there are obvious gaps between long-term change in economic structure and its principal driving force-technological progress. History has shown the influence of technological progress on the economy and current insights in technological development can almost predict the technological waves of the next 50 years, but their potential impact on the economy has not yet been assessed. In this paper, we aim to simulate the evolution of economic structure as represented by input-output structure under specific technological change. A new version of a dynamic input-output model is developed, in which both technological progress and deployment are endogenous. Investment in $\mathrm{R} \& \mathrm{D}$ drives the development of new technologies, installation of capital stock brings new technical processes into sector production, new and old technical processes within a sector exchange their relative weights in production as they are phased in or out, and sectors evolve or transform over time. Scenario analysis using this model applied to the Chinese electric power industry shows that the phasing-in of non-fossil energy technology will greatly change the structure of both the sector and the economy over the next 100 years (Pan, 2006).

The authors of another scientific article develop a tractable, three-sector model to study structural change in an open economy. The model features an endogenous pattern of trade dictated by comparative advantage. The authors derive an intuitive expression linking sectoral employment shares to sectoral expenditure shares and to sectoral net export shares of total GDP. The authors show how these driving forces can generate the "hump" pattern that characterises the manufacturing employment share as a country 
develops, even when manufacturing is the sector with the highest productivity growth (Yi and Zhang, 2010).

One more paper employs an input-output framework to identify the contribution of economy-wide changes in technology and international trade to sectoral output growth in the German economy over the 1990s. Distinguishing two manufacturing sectors, a manufacturing core of export-oriented sectors and the rest of manufacturing, it subsequently formulates several scenarios about structural changes that are assumed to take place in each of these subsectors. Comparing the resulting output and employment to actual base-year values, the authors can thus identify the impact of the most important changes within manufacturing on, in particular, two subsectors of business-related services. The quantitative analysis establishes the order of magnitude-which is considerable-by which the latter have profited from structural changes in the manufacturing sector (Franke, Kalmbach, 2005).

This paper examines the emergence of manufacturing in developing countries in the period 1950-2005. It presents new data on structural change in a sample of 67 developing countries and 21 advanced economies. The paper examines the theoretical and empirical evidence for the proposition that industrialisation acts as an engine of growth in developing countries and attempts to quantify different aspects of this debate. The statistical evidence is not completely straightforward. Manufacturing has been important for growth in developing countries, but not all expectations of the engine of growth hypothesis' are borne out by the data. The more general historical evidence provides more support for the industrialisation thesis (Szirmai, 2012).

The diversity of technological activities that contribute to growth in labour productivity is examined in another article for manufacturing and services industries in eight major EU countries. Its authors test the relevance of two "engines of growth", i.e., the strategies of technological competitiveness (based on innovation in products and markets) and cost competitiveness (relying on innovation in processes and machinery) and their impact on economic performance. The authors propose models for the determinants of changes in labour productivity and they carry out empirical tests for both the whole economy and for the four Revised Pavitt classes that group manufacturing and services industries with distinct patterns of innovation. Tests are carried out by pooling industries, countries and three time periods, using innovation survey data from CIS 2, 3 and 4, linked to economic variables. The results confirm the specificity of the two "engines of growth"; economic performances in European industries appear as the result of different innovation models, with strong specificities of the four Revised Pavitt classes (Bogliacino and Pianta, 2011).

The following paper analyses the determinants of structural change and aggregate productivity growth on the basis of the aggregation of the behaviours of heterogeneous firms in different economic sectors. At the same time, this model accounts for the evolution of market by providing a consistent generalisation of standard replicator dynamic models, which focus only on a single industry. This paper shows that understanding structural change has to be grounded on a macroeconomic consistent aggregation mechanism reflecting the underlying theory of sorting and selection. It also shows that the combined effect on sectoral output growth of selection on firms' unit costs and sort- 
ing by income elasticities of sectoral demand depends upon the specific institutional characteristics of the market, upon the specific position that a sector occupies in the whole economy, in terms of product characteristics and substitutability and, finally, upon the output growth and average unit costs of substitute sectors. Moreover, the selection process and the institutional settings in which it unfolds, combined with sectoral income elasticities, guide aggregate productivity growth, which can display positive values even without technological change at firm level (Montobbio, 2002).

This paper investigates how countries become specialised in exporting specific producer services, particularly financial, communication and business services. The authors find that a country's ability to develop a competitive service economy depends on the structure of its manufacturing sector, as some manufacturing industries are more intensive users of these services. Moreover, the authors find a virtuous cycle, as the same service producers are also intensive users of these producer services. Finally authors find that information and communication technologies have a significant impact on trade performance of these producer services (Guerrieri and Meliciani, 2005).

A study entitled "Engines of Growth in the US Economy" implies that there is good reason to believe that R\&D influences on TFP (total factor productivity) growth in other sectors are indirect. For R\&D to spill over, it must first be successful in the home sector. Indeed, observed spillovers conform better to TFP growth than to R\&D in the upstream sectors. Sectoral TFP growth rates are thus inter-related. Solving the inter-sectoral TFP equation resolves overall TFP growth into sources of growth. The solution essentially eliminates the spillovers and amounts to a novel decomposition of TFP growth. The top 10 sectors are designated 'engines of growth' led by computers and office machinery. The results are contrasted with the standard, Domar decomposition of TFP growth (Raa, Wolff, 2000).

This paper explores the relation between countries' pattern of trade specialisation and long-term economic growth. It shows that countries specialising in the export of natural resource based products only fail to grow if they do not succeed in diversifying their economies and export structure. This conclusion follows from an empirical investigation that has three innovative features. First, it uses a dynamic panel data analysis. Secondly, it employs disaggregated trade data sets to elaborate different measures of trade specialisation that distinguish between unprocessed and manufactured natural resource products and are informative about the countries' trade diversification experience, their link to world demand trends and involvement in intra-industry trade. The final innovative aspect of the paper relates to our empirical findings: it is only specialisation in unprocessed natural resource products that slows down economic growth, as it impedes the emergence of more dynamic patterns of trade specialisation (Mursheda, Serinoc, 2011).

In a research entitled "Structural Convergence of European Countries" its authors investigate the development of economic structures of Western European countries over the last three decades using employment data. The authors test for structural convergence on the aggregate level as well as specifically for manufacturing and service industries. For this the authors implement both time-series and panel data methods. The results show strong and persistent inter-sectoral convergence patterns as lagging countries shift from industrialised to service economies. In contrast, the results regarding inter-industry con- 
vergence are mixed: due to one-country specialisation effects, increasing divergence is dominant in technology-intensive manufacturing industries, which are characterised by economies of scale, path-dependency and strong economic growth. In less technologyintensive industries both convergence and divergence trends are found, depending on the existence of economies of scale. In traditional service branches, country-specific differences do not change to a significant extent, whereas in some industries with potential for rationalisation, convergence prevails (Palana, Schmiedebergb, 2010).

This study contributes to the understanding of the regional structure of the Chilean economy utilising the fundamental economic structure (FES) approach. The regional FES construct implies that selected characteristics of an economy will vary predictably with economic size, as measured by regional: domestic product, population, total value added, and total sector output. The overarching problem addressed in this research is whether identifiable patterns of relations among regional macro aggregates and economic transactions can be revealed via regional input-output tables. Jensen, West and Hewings discuss the tiered, partitioned, and temporal approaches to the identification of FES using regional input-output table and spatial economic data. This research addresses the following four research questions: (1) Does a regional FES exist for the Chilean economy? (2) What proportions of the cells are predictable? (3) Can stability patterns in the intermediate transaction table be identified for Chilean regional economy? (4) Which economic transactions are the most important across regional economies in Chile? Four regression models: linear-linear, linear-logarithmic, linear-inverse, and linear-logarithmic of inverse are run to identify the largest proportion of predictable FES cells for the Chilean regional economy. The regional input-output tables (1996) for the 13 regions compiled by the National Institute of Statistics of Chile provide data for the analysis. A FES analysis shows that $75 \%$ cells are predictable, $34 \%$ are stable, and $25 \%$ are important for Chilean regional economies. Further, $7 \%$ of the total fundamental economic activities are predictable, stable and important simultaneously. These strong FES-based economic activities consist of chemicals, rubber, petroleum, and plastics as well as public services among several other fundamental industries (Thakur, Alvayay, 2012).

Another paper presents a structuralist North-South model on structural change, industrialisation and economic convergence. In a balance-of-payments-constrained macro-setting, authors assume a cumulative process between industrialisation and growth. Different from the traditional post-Keynesian models, the authors endogenise the productive structure of developing countries. The authors enquire how industrialisation affects uneven development and convergence processes. Multiple growth paths and a long-run path-dependent equilibrium emerge. Industrialisation proves to be a necessary but not sufficient condition for catching-up. Good management by the domestic institutions of domestic industrialization is a complementary requirement (Botta, 2009).

One more paper proposes an economic model to analyse a dynamic interaction among capital accumulation, economic structure and preference in a perfectly competitive economic system. The system consists of three sectors: agriculture, industry and service. A typical consumer's utility is dependent on consumption of agricultural and industrial goods, services, housing and wealth. The territory size is given and public land ownership is assumed. The model in this study is influenced by the structural ap- 
proach of, for example, Leontief, Sraffa and Pasinetti. The traditional neoclassical growth models, such as the Solow-Swan one-sector model, the Uzawa two-sector model and the Ricardian models of Samuelson and Pasinetti, may be considered, from a structural point of view, as special cases of the model in this study. Conditions for the existence of equilibria and stability are provided. The effects of changes in some parameters on the long-run economic structure are examined (Zhang, 1996).

The objective of the next paper is to summarise the essential aspects and types of structural change that may contribute to the development of a general theory. First, a brief ontological introduction presents the underlying worldview and clarifies the meaning of key terms. Second, the basic general mechanisms of structural change are explored and relations among them are pointed out. Finally, some considerations are made about the use of the developed concepts in the prediction, analysis, and management of structural change situations (Domingo, Tonella, 2000).

This paper shows that levels and trends of comparative labour productivity in manufacturing differ from levels and trends of labour productivity at the whole economy level, suggesting that structure and structural change play an important role in the growth process. Persistent differences of productivity levels are related to the choice between standardised mass production and craft flexible production technologies. These technological choices are shown to affect the development of human capital because of the different requirements of the two systems for shop floor, management and research skills (Broadberry, 1995).

The main characteristics of economic growth of nations are a sustained increase in the growth of output and factor productivity and a widespread process of structural transformation. In their paper, the authors contrast two of the few important authors that do not ignore structural change: Kuznets and Pasinetti. Over several decades, the two approaches have developed in an almost orthogonal manner. The authors discuss the reasons and evaluate the relevance of the approaches for the study of economic development (Syrquin, 2010).

The relationship between economic structure and productivity growth has been the subject of increasing interest over recent decades. The innovative focus of this paper concerns the role of the service sector in this relationship. Services play a core role in advanced economies, both from a quantitative and a strategic point of view. However, empirical research in this area lies considerably behind the research into the agricultural and manufacturing sectors. This paper focuses on the impact of tertiarisation on overall productivity growth, using a sample of 37 OECD countries in the period between 1980 and 2005. The results partially refute traditional knowledge on the productivity of services. Contrary to what conventional theories suggest, this research demonstrates that several tertiary activities have shown dynamic productivity growth rates, while their contribution to overall productivity growth plays a more important role than was historically believed (Maroto-Sanchez, Cuadrado-Roura, 2009).

In his article, Fagerberg (2000) finds changes in the employment share of the electrical machinery industry to positively impact the manufacturing sector productivity growth. Fagerberg's approach has some methodological drawbacks, however. This note seeks to complement Fagerberg's analysis by estimating the impact of the employment 
share of technologically progressive industries using a more adequate methodology. Fagerberg's claim that the share of the 'electronics' industry positively affects manufacturing is confirmed. However, the size of the impact, and as a consequence the extent of spill-overs, is found to be much smaller than estimated by Fagerberg (Carree, 2003).

The paper investigates the driving forces behind the recent stages of this development. Focusing on international input-output data from the early 1970s to the 1990s, a decomposition analysis separates the quantitative impact of demand, technology and trade determinants of output growth. The findings confirm the rise of knowledge- based services as the most dynamic component, thus strengthening the case for "quarterisation", as a process which is distinctly characterised by the substantial contribution of technological and organisational change to structural development (Peneder et al., 2001).

The authors estimate total factor productivity (TFP) growth in agriculture, industry and services in the new European Union Member States and show how structural change contributes to growth. Because of the difficulties in measuring the capital stock of transition economies, we develop a model that estimates sectoral TFPs from data on sectoral employment and GDP per capita. Compared to Austria, new EU Member States have lower TFP levels, but their TFP growth is largely higher. Inter-sectoral movements of labour do not play a large role in aggregate TFP growth, and capital accumulation is an important component of convergence to EU levels of per capita GDP (Bah, Brada, 2009).

Another paper documents the comparative productivity performance of the United States and Britain since 1870, showing the importance of developments in services. The authors identify the transition in market services from customised, low-volume, highmargin business organised on a network basis to standardised, high-volume, low-margin business with hierarchical management, as a key factor. A model of the interaction between technology, organisation and economic performance is then provided, focusing on the transition from networks to hierarchies. Four general lessons are drawn: (1) developments in services must be analysed if the major changes in comparative productivity performance among nations are to be understood fully; (2) different technologies and organisational forms can co-exist efficiently; (3) technological change can cause difficulties of adjustment in technology-using sectors if it is not suited to the social capabilities of the society; (4) reversal of technological trends can lead to reversal of comparative productivity performance (Broadberry, Ghosal, 2005).

In a research entitled "The Service Paradox and Endogenous Economic Growth" (2006) it is stated that "stagnant services" are characterised by low productivity growth and rising prices, but also, and paradoxically, by output growth proportional to the rest of the economy, and hence by an expanding employment share, with a negative effect on aggregate productivity growth. The paper considers that many of these services, inclusive of education, health and cultural services, contribute to human capital formation, thus enhancing growth. This effect is distinguished according to whether it is a side-effect of spending on services or an intentional investment by households, as in Lucas' model. Preferences for services are assumed to rise with income. The main result is that the productivity of stagnant services and their quality displayed in raising human capital play a central role in opposing the negative Baumol effect on growth, and in reinforcing the explanation of the paradox (Pugno, 2006). 
The other paper investigates empirically whether the growing service sector in China leads to cost disease, a likely consequence of tertiarisation according to Baumol's unbalanced growth model. The investigation uses a panel data set of 30 provinces. The key findings are: the currently positive contribution of the service sector to growth is largely due to shifts of labour from the primary sector into services; however, signs of cost disease are discernible from weak responses to price signals in demand for services, in wage determination and labour input demand of the service sector (Qin, 2006).

\section{Conclusions}

Insufficient attention to the impact of economic sectors on Lithuania's economic development encouraged a very reasonable necessity for foreign literature analysis on this topic. In order to provide an in-depth coverage of possible contemporary perceptions of economic sector performance and economic growth, many pieces of foreign relevant scientific literature were overviewed in the context of sustainability. The main insights have been distinguished:

- The structure of a country's economy is the key factor that differentiates successful countries from unsuccessful ones and is of vital importance for economic growth.

- Economic structure $\rightarrow$ Economic sectors $\rightarrow$ Economic sector performance $\rightarrow$ Economic growth

- Foreign scientists most commonly define economic sector performance targeted at a country's economic growth as structural changes.

- Economic sector performance targeted at a country's economic growth through the perspective of inputs to production cannot be implied without productivity phenomenon in the context of sustainable development.

- An overview of economic sector performance, productivity and economic growth methodologies is needed for further elaboration of this topic.

\section{References}

1. Bond, S.; Leblebiciog, A.; Schiantarelli, F. (2010). Capital accumulation and growth: a new look at the empirical evidence, Journal of Applied Econometrics 25: 1073-1099.

2. Briec, W.; Cavaignac, L. (2009). An extension of the multi-output state-contingent production model, Economic Theory 39: 43-64. http://dx.doi.org/10.1007/s00199007-0308-6

3. Balkyte, A.; Tvaronaviciene, M.(2011). The role of migration for Sustainable developing economy: Lithuania in the EU context, Journal of Security and Sustainability 1(2): 133-145. http://dx.doi.org/10.3846/jbem.2010.17

4. Balkyte, A.; Tvaronaviciene, M.. (2010). Perception of competitiveness in the context of sustainable development: facets of "Sustainable competitiveness", Journal of Business Economics and Management 11(2): 341-365. 
5. Balciunas, N. (2000). Lietuvos pramones prioritetu igyvendinimas ir valstybes remiamu programu rengimo butinumo ekonominis, socialinis, finansinis pagrindimas. Organizaciju vadyba: sisteminiai tyrimai, Vytautas Magnus University, T. 13.P. 7-17.

6. Bogliacinoa, F., Piantac. M..(2011). Engines of growth. Innovation and productivity in industry groups, Structural Change and Economic Dynamics 22:41-53.

7. Botta, A. (2009). A structuralist North-South model on structural change, economic growth and catching-up, Structural Change and Economic Dynamics 20: 61-73.

8. Broadberry, S.N. (1995). Comparative productivity levels in manufacturing since the Industrial Revolution: Lessons from Britain, America, Germany and Japan, Structural Change and Economic Dynamics 6:71-95

9. Bah, M.E.; Brada, J.C. (2009). Total Factor Productivity Growth, Structural Change and Convergence in the New Members of the European Union, Comparative economic studies 51:421-446.

10. Broadberry,S., Ghosal, S. (2005). Technology, organization and productivity performance in services: lessons from Britain and the United States since 1870, Structural Change and Economic Dynamics 16: 437-466.

11. Ciegis, R.; Ramanauskiene, J. (2009). Sustainable development and its assessment, Applied Economics: Systematic Research 3(2):143-153.

12. Castellacci, F. (2010). Structural change and the growth of industrial sectors: empirical test of a GPT model, Review of income and wealth, 56(3):449-482.

13. Carree, M.A.(2003). Technological progress, structural change and productivity growth: a comment, Structural Change and Economic Dynamics 14:109-115.

14. Domingo, C., Tonella, G. (2000). Towards a theory of structural change, Structural Change and Economic Dynamics 11:209-225.

15. Franke, R., Kalmbach, P.(2005). Structural change in the manufacturing sector and its impact on business-related services: an input-output study for Germany, Structural Change and Economic Dynamics 16:467-488.

16. Fagerberg, J. (2000). 'Technological progress, structural change and productivity growth: a comparative study', Structural Change and Economic Dynamics, Vol. 11, No. 4, pp. 393-412.

17. Grybaitè, V.; Tvaronavičienè, M. (2008). Estimation of sustainable development: germination on institutional level, Journal of Business Economics and Management (9)4: 327-335. ISSN 1611-1699.

18. Guerrieri, P., Meliciani V.(2005). Technology and international competitiveness: The interdependence between manufacturing and producer services, Structural Change and Economic Dynamics 16: 489-502.

19. Halkos, G.; Tzeremes, N. (2008). Trade efficiency and economic development: evidence from a cross country comparison, Applied Economics 40:2749-2764.

20. Havlik, P. (2005).Structural Change, Productivity and Employment in the New EU Member States, the Vienna Institute for International Economic Studies, wiiw Research Reports, 313.

21. Huber, P., Mayerhofer, P. (2006). Structural Change in the CENTROPE Region, workshops proceedings of oenb workshops, No 9. 
22. Hein, E., Truger, A. (2005). European Monetary Union: nominal convergence, real divergence and slow growth? Structural Change and Economic Dynamics 16, 7-33.

23. Jaimovich, E. (2011). Sectoral differentiation, allocation of talent, and financial development, Journal of Development Economics 96: 47-60.

24. Palana, N., Schmiedebergb, C.(2010). Structural convergence of European countries, Structural Change and Economic Dynamics 21: 85-100.

25. Pan, H. (2006). Dynamic and endogenous change of input-output structure with specific layers of technology, Structural Change and Economic Dynamics, 17:200-223.

26. Kosempel, S.. (2004). A theory of development and long run growth, Journal of Development Economics 75: 201-220.

27. Karnitis, E. (2011). Strategy and efficient mechanisms to improve security and sustainability of the natural gas supply in Baltic States, Journal of Security and Sustainability Issues 1(1): 3-15 [interactive], [accessed on 23 October 2012] <http://www.lka.lt/EasyAdmin/sys/files/Journal\%20of\%20Security\%20and\%20 Sustainability\%20Issues_VIRSELIS+KNYGA_Internetui.pdf>

28. Kaźmierczyk, J. (2012). Information technology systems and their impact on the employment level in the polish banking sector, Journal of Security and Sustainability Issues 1(3): 187-195.

29. Kuznets, S. (1966). Modern economic growth: rate, structure and spread. Yale University Press, London.

30. Kuznets, S. (1979). Growth, population, and income distribution: Selected essays. Norton, New York.

31. Qin., D.(2006). Is China's growing service sector leading to cost disease? Structural Change and Economic Dynamics 17: 267-287.

32. Lankauskienè, T.; Tvaronavičienė, M. (2011). Interrelation of countries' developmental level and foreign direct investments performance, Journal of Business Economics and Management 2011 12(3):546 - 565 DOI:10.3846/16111699.2011.599412

33. Lankauskienè, T.; Tvaronavičienè, M.(2012). Security and sustainable development: approaches and dimensions in the globalization context, Journal of Security and Sustainability Issues 1(4): 285-295.

34. Lewis, W.A. (1954). Economic development with unlimited supplies of labor. Manchester Sch Econ Soc Stud 22:139-191.

35. Lankauskiene,T.; Tvaronaviciene, M.. (2012). Production factors and structural changes in economy sectors: genesis of theoretical approaches. Contemporary issues in business, management and education'2012, Vilnius, Lithuania: selected papers: conference proceedings. Vilnius: Technika, 2012. (Contemporary issues in business, management and education, 2029-7963). ISSN 2029-7963. ISBN 9786094573231. p. 245259. <http://cbme.vgtu.lt/index.php/cbme/cbme_2012/schedConf/presentations>.

36. Maroto-Sanchez, A., Cuadrado-Roura, J.R. (2009). Is growth of services an obstacle to productivity growth?A comparative analysis, Structural Change and Economic Dynamics 20:254-265.

37. Misiunas, P., Kaminskiene, B. (1999). Pagrindinės pramonès pokyčių tendencijos. Lietuvos ūkis: ekonominès minties žurnalas, Nr.1, P.21-23 
38. Matuzeviciute, K., Skuncikienè, S., Tamasaityte, E. (2010). Baltijos šalių BVP struktūrinių pokyčių analizè. Ekonomika ir vadyba: aktualijos ir perspektyvos, Nr. 2(18), p. 78-88.

39. Montobbio, F. (2002). An evolutionary model of industrial growth and structural change, Structural Change and Economic Dynamics 13: 387-414.

40. Mursheda, M.S., Serinoc, L.A. (2011). The pattern of specialization and economic growth: The resource curse hypothesis revisited, Structural Change and Economic Dynamics 22:151-161.

41. Raa, T., Wolff, E.N..(2000). Engines of growth in the US economy, Structural Change and Economic Dynamics 11:473-489.

42. Peneder, M. (2009). Sectoral growth drivers and competitiveness in the European Union. European Commission, Enterprise and Industry, European Communities, p.1-542.

43. Peneder, M. (2003). Industrial structure and aggregate growth, structural change and economic dynamics 14:427-448.

44. Peneder, M., Kaniovski, S., Dachs, B. (2001). What follows tertiarisation? Structural change and the role of knowledge- based services. WIFO working papers, No. 146

45. Pisani, D., Jacobus, A. (2006). Sustainable development- historical roots of the concept, Environmental Sciences, 3(2): 83-96.

46. Pugno, M. (2006). The service paradox and endogenous economic growth, Structural Change and Economic Dynamics 17: 99-115.

47. Ruchi, M. (2009). Sustainable development- how far is it sustainable? Proceedings of World Academy of Science, Engineering \& Technology (51): 754-757.

48. Sonobe,T.; Hu, D.; Otsuka, K. (2004). From inferior to superior products: an inquiry into the Wenzhou model of industrial development in China, Journal of Comparative Economics 32:542-563.

49. Sarkar, D. (2007). The role of human capital in economic growth revisited, Applied Economics Letters 14: 419-423.

50. Stańczyk, J. (2011). European security and sustainability issues in the context of current international environment, Journal of Security and Sustainability Issues 1(2): 81-90.

51. Stanciu, M.; Mangra, M.; Daea, A. (2010). The concept and the strategy of sustainable development, Young Economists Journal Special Issue (8):125-136

52. Stankevicius, P. (2006). Lietuvos ukio pokyciai XX a. Istorija, mokslo darbai, Vilniaus pedagoginis universitetas p.66-76.

53. Szirmai, A. (2012). Industrialisation as an engine of growth in developing countries, 1950-2005, Structural Change and Economic Dynamics 23: 406-420.

54. Syrquin, M. (2010). Kuznets and Pasinetti on the study of structural transformation: Never the Twain shall meet? Structural Change and Economic Dynamics 21:248-257.

55. Tanuwidjaja, E.; Thangavelu, S. (2007). Structural Change and Productivity Growth in the Japanese Manufacturing Industry, Global Economic Review 36(4): 385-405.

56. Tvaronaviciene, M.; Lankauskiene, T. (2011). Plausible foreign direct investment impact on sustainable development indicators of differently developed countries, Journal of Security and Sustainability Issues 1(1): 25-36. 
57. Tvaronaviciene, M.; Lankauskiene, T.(2012). Should consistent patterns be traced: impact of globalization on certain sustainable development facets, Socialiniu moksly studijos, 4(2): 443-468.

58. Timmer, M.P.; Vries, G.J. (2008). Structural change and growth accelerations in Asia and Latin America: a new sectoral data set, cliometrica, DOI 10.1007/s11698-008-0029-5.

59. Timmer, M.P.; Vries, G.J. (2007). A Cross-country Database For Sectoral Employment And Productivity In Asia and Latin America, 1950-2005.

60. Timmer, M.P., Szirmai, A. (2000). Productivity growth in Asian manufacturing: the structural bonus hypothesis examined, Structural Change and Economic Dynamics 11:371-392.

61. Thakur, S.K., Alvayay, J.R. (2012). Identification of regional fundamental economic structure (FES) of Chilean economy: A field of influence approach, Structural Change and Economic Dynamics 23:92-107.

62. Tvaronaviciene, M., Lankauskiene, T. (2013). The impact of production factors and economic structures on economic development, Business: Theory and Practice, 14(1):5-16, doi:10.3846/btp.2013.01.

63. Vitas, A. (2012). Baltijos saliu ukio strukturiniu pokyciu analize ir vertinimas, daktaro disertacija, Vilnius VU.

64. Vries, G.J., Erumban, A.A., Timmer, M.P., Voskoboynikov, I., Wu, H.X. (2012). Deconstructing the BRICs: Structural transformation and aggregate productivity growth, journal of comparative economics, 40 (2): 211-227.

65. Vries, G.J., Erumban, A.A., Timmer, M.P., Voskoboynikov, I., Wu, H.X. (2011). Deconstructing the BRICs: Structural Transformation and Aggregate Productivity Growth, research memorandum GD-121, Groginen growth and development centre, University of Groginen.

66. Yi, K., Zhang, J. (2010). Structural Change in an Open Economy.

67. Zhang, W. (1996). Preference, structure and economic growth, Structural Change and Economic Dynamics 7:207-221.

\section{EKONOMIKOS SEKTORIŲ VEIKLA IR AUGIMAS: ŠIUOLAIKINIAI POŽIŪRIAI DARNAUS VYSTYMOSI KONTEKSTE}

Santrauka. Nepakankamas dėmesys ekonomikos sektorių įtakos augimui Lietuvoje suponavo ypatingą šios tematikos užsienio literatūros apžvalgos poreikį. Turint tikslą pateikti detalią ir išsamią ekonomikos sektorių ir augimo šiuolaikinių požiūrių studiją, buvo peržiūrèta didelè imtis užsienio mokslinès literatūros darnios plètros klausimais. Pagrindinès tyrimo įžvalgos: ekonomikos struktūra yra vienas iš pagrindinių faktorių, skiriantis sèkmingai besivystančias šalis nuo nesèkmingai ir turi ypatingą svarbą šalies ekonominiam augimui; ekonomikos sektorių veikla, orientuota ị ekonominị augimą, užsienio mokslininkų dažniausiai apibrèžiama kaip struktūriniai pokyčiai; ekonomikos sektorių veikla, orientuota ị ekonominị augimą, per gamybos veiksnių prizmę negali atsiriboti nuo produktyvumo koncepcijos darnios pletros kontekste. 
Toma LANKAUSKIENĖ. PhD in Economics at Vilnius Gediminas Technical University, Faculty of Business Management, Department of Economics and Management of Enterprises. Scientific research area: structural economics, development economics, sustainable development.

Toma LANKAUSKIENĖ, Vilniaus Gedimino technikos universiteto Verslo vadybos fakulteto İmonių ekonomikos ir vadybos katedros doktorantė (ekonomikos krypties). Mokslinių tyrimų sritys: struktūrų ekonomika, vystymosi ekonomika, darni plètra.

Manuela TVARONAVIČIENĖ. Dr. in Economics; Professor at Vilnius Gediminas Technical University, Faculty of Business Management, Department of Economics and Management of Enterprises. Scientific research area: economic growth, investment, innovations, economic sector development.

Manuela TVARONAVIČIENĖ, Vilniaus Gedimino technikos universiteto Verslo vadybos fakulteto İmonių ekonomikos ir vadybos katedros profesoré, ekonomikos mokslų daktarè. Mokslinių tyrimų sritys: ekonominis augimas, investicijos, inovacijos, ekonomikos sektorių vystymasis. 